\title{
Pain as a determinant of the emotional state of women after radical cancer surgery and chemotherapy
}

\section{Ból jako czynnik determinujacy stan emocjonalny kobiet po radykalnym leczeniu chirurgicznym raka piersi oraz chemioterapii}

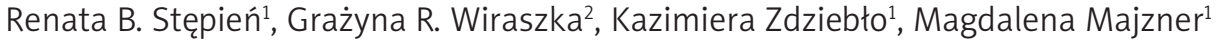 \\ 'Department of Internal Diseases, Cardiology and Medicine Nursing, Institute of Nursing and Obstetrics, Faculty of Sciences, \\ Jan Kochanowski University, Kielce, Poland \\ Head of the Department: Prof. Marianna Janion MD, PhD \\ 2Department of Oncology and Nursing Oncology, Institute of Nursing and Obstetrics, Faculty of Sciences, Jan Kochanowski University, \\ Kielce, Poland \\ Head of the Department: Prof. JKU Maciej Kielar MD, PhD
}

Studia Medyczne 2014; 30 (4): 241-246

DOI: $10.5114 / \mathrm{ms} .2014 .47922$

Key words: cancer pain, mastectomy, chemotherapy.

Słowa kluczowe: ból nowotworowy, mastektomia, chemioterapia.

\begin{abstract}
Introduction: Cancer pain is chronic pain resulting from various mechanisms related to the natural history of the disease, the course of therapy, and psychosocial factors.

Aim of the research: To assess the relationship between the intensity of cancer pain in women at the final stage of chemotherapy following radical surgery of breast cancer, and the intensity of negative emotional reactions.

Material and methods: The study was conducted in a population of 118 women after radical surgical treatment of breast cancer and undergoing chemotherapy at the Chemotherapy Unit of the Holycross Cancer Centre in Kielce in 2011. The research methodology consisted of a diagnostic survey and medical documentation review.

Results: Strong emotional stress manifested by anxiety and depression was experienced by $48.3 \%$ and $29.7 \%$ of patients, respectively. Aggression was experienced by $15.2 \%$. Intensification of pain was associated with the intensification of anxiety $(r=0.37 ; p<0.0001)$, depression $(r=0.35 ; p<0.01)$, and aggression $(r=0.30 ; p<0.01)$.

Conclusions: Adherence to the WHO-recommended analgesic ladder regimen is an effective means to treat chronic cancer pain in women in the final stage of chemotherapy following radical surgical treatment. Effective pharmacotherapy of cancer pain significantly contributes to a reduction in the intensity of negative emotional reactions, i.e. anxiety, depression, and aggression in patients undergoing chemotherapy following mastectomy. Breast cancer chemotherapy is associated with high levels of anxiety, pain, and aggression being experienced by the patients. Pain is an important determinant of the emotional state of women undergoing chemotherapy following radical cancer surgery.
\end{abstract}

\section{Streszczenie}

Wprowadzenie: Ból nowotworowy jest bólem przewlekłym o wielorakich mechanizmach powiązanych z istotą choroby, przebiegiem jej terapii, a także czynnikami psychospołecznymi.

Cel pracy: Ocena zależności między natężeniem bólu nowotworowego u kobiet po radykalnym leczeniu chirurgicznym raka piersi będących w końcowym etapie chemioterapii a nasileniem negatywnych reakcji emocjonalnych.

Materiał i metody: Badaniem objęto 118 kobiet po radykalnym leczeniu chirurgicznym raka piersi oraz poddanych chemioterapii na Oddziale Chemioterapii Świętokrzyskiego Centrum Onkologii w Kielcach w 2011 roku. Metody badawcze stanowiły sondaż diagnostyczny oraz analiza dokumentacji medycznej.

Wyniki: Silnego stresu emocjonalnego w postaci lęku i depresji doświadczało odpowiednio 48,3\% i 29,7\% pacjentek, a agresji 15,2\%. Intensyfikacja bólu korelowała z nasilaniem się u badanych lęku $(r=0,37 ; p<0,0001)$, depresji $(r=0,35 ; p<0,01)$ oraz agresji $(r=0,30 ; p<0,01)$.

Wnioski: Zachowanie rekomendowanego przez Światową Organizację Zdrowia schematu leczenia przeciwbólowego w postaci tzw. drabiny analgetycznej stanowi skuteczną formę terapii przewlekłego bólu nowotworowego u kobiet po radykalnym leczeniu chirurgicznym, będących w końcowej fazie chemioterapii. Efektywna farmakoterapia bólu nowotworowego istotnie wpływa na redukcję nasilenia negatywnych reakcji emocjonalnych, tj. lęku, depresji oraz agresji, u pacjentek po mastektomii z wdrożoną chemioterapią. Chemioterapia raka piersi wiąże się z przeżywaniem przez chore wysokiego natężenia lęku, depresji oraz agresji. Ból stanowi istotny objaw determinujący stan emocjonalny kobiet po radykalnym leczeniu chirurgicznym raka piersi poddawanych chemioterapii. 


\section{Introduction}

Pain is a psychosomatic phenomenon that has been defined by the International Association for the Study of Pain (IASP) as "an unpleasant sensory and emotional experience associated with actual or potential tissue damage, or described in terms of such damage". This definition highlights two primary components of pain, i.e. the sensory component, associated with the perception of pain, and the emotional component, related to mental reaction to the experienced pain stimulus; the latter has a very individual character [1]. The tolerance of pain and the efficacy of analgesic treatment may be determined by a number of factors regardless of the site and the nature of the tissue-damaging stimulus. The most common factors that reduce the pain tolerance include exacerbation of cancer symptoms, insomnia, anxiety, depression, and the feelings of abandonment and weariness of the disease. On the other hand, sleep, effective oncological treatment, mood elevation, the presence of relatives and friends, and activity improve the pain tolerance [1-3].

Pain is estimated to occur in ca. $30-50 \%$ of patients in the early stages of cancer, while the percentage of advanced cancer patients requiring constant delivery of analgesics is about $75 \%$. In the group of patients with metastatic cancer, the percentage reaches $100 \%$ $[2,4,5]$.

According to estimates, about $85-90 \%$ of patients with cancer pains may be effectively treated with pharmacological methods. The worldwide standard in pain therapy is regular administration of drugs of increasing potency once those less potent become ineffective, and a combination of different analgesics according to the regimen proposed by the World Health Organisation (1986, 1990, 1996). The Polish position on cancer pain management is constantly verified and updated. The current basic principles for the management of pain in patients suffering from cancer or other chronic, progressive, and life-threatening diseases were developed by the Coalition Against Pain. The principles were developed on the basis of recommendations of the established scientific associations, including those of the European Association for Palliative Care (2012), the European Society for Medical Oncology (2012), the Polish Association for Palliative Medicine (2009), as well as recent systematic reviews of scientific articles [5, 6].

\section{Aim of the research}

The goal of the study presented in the article was to assess the relationship between the intensity of cancer pain in women at the final stage of chemotherapy following radical surgery of breast cancer and the intensity of negative emotional reactions, i.e. anxiety, depression, and aggression as well as selected sociodemographic variables.

\section{Material and methods}

The study was conducted in a population of 118 women experiencing chronic pain and undergoing chemotherapy after radical surgical treatment of breast cancer. The study was conducted in patients receiving the last course of cytotoxic drugs at the Chemotherapy Unit of the Holycross Cancer Centre in Kielce in 2011. Patient participation was voluntary. Patients were informed about the goal of the study and the confidentiality ways the data collected in the study would be used. Patients expressed their informed consent to participate in the study.

The research methodology consisted of a diagnostic survey and a review of medical documentation, i.e. medical histories and individual medical prescription cards. The pain intensity assessment tool consisted of a numerical rating scale (NRS) that permitted the assessment of the variable of interest in the range 0 (no pain) to 10 (worst pain imaginable). Patient-reported NRS scores of 1-3 correspond to mild pain, scores of 4-6 correspond to moderate pain, and scores of $7-10$ correspond to severe pain $[5,6]$. The levels of anxiety, depression, and aggression were assessed using the HADS-M questionnaire - a Polish adaptation of the Hospital Anxiety and Depression Scale (HADS) by A. Zigmond and R. Snaith. Hospital Anxiety and Depression Scale is used in screening of anxiety and depression levels. The assessment of each of these emotional aspects consists of seven subscale-specific questions. Each question may be graded within the range of $0-3$ points. The following score ranges were identified for both anxiety and depression subscales: 0-7 - normal level, 8-10 - borderline level, 11-21 high level. Modification and Polish adaptation of the HADS-M questionnaire was done by Majkowicz, de Walden-Gałuszko, and Chojnacka-Szawłowska. The original version of the scale was expanded by two aggression-related questions, each graded within the range of 0 to 3 points [7].

\section{Statistical analysis}

Statistical analysis was performed using the $\chi^{2}$ test, the $Z$ test, and the Kruskal-Wallis $H$ test.

\section{Results}

The study subjects were in the age range 25 to 85 years. The mean age was 56.2 years $(\mathrm{SD}=15.45)$. $\mathrm{Pa}-$ tients participating in the study were most commonly of secondary education level ( $n=48 ; 40.7 \%)$. Smaller numbers of patients fell into the groups of higher education ( $n=32 ; 27.1 \%)$, vocational education $(n=32$; $27.1 \%)$, and primary education $(n=6 ; 5.1 \%)$. The vast majority of patients were married $(n=68 ; 57.6 \%)$ and were town residents $(n=62 ; 52.5 \%)$.

The study subjects assessed the pain intensity using a 10-point NRS scale; the results were in the range 
1 to 8 , with a mean score of $3.09(\mathrm{SD}=1.75, \mathrm{Me}=3$ ). The analysis of the analgesic treatment was conducted in accordance with the three-step WHO analgesic ladder. Nearly $50 \%$ of the patients experiencing pain ( $n=58 ; 49.2 \%)$ received non-opioid analgesics; mild opioid analgesics were used in $32.2 \%(n=38)$, and strong analgesics were used in $18.6 \%(n=22)$ of patients. Medications used at the first step of the analgesic ladder included acetylsalicylic acid (0.5-1.0 g every 4-6 h), and paracetamol (0.5-1.0 g every 4-6 h). Medications of the second step of the analgesic ladder included codeine ( $0.03-0.06 \mathrm{~g}$ p.o. every $4-6 \mathrm{~h})$, tramadol (0.05-0.1 g p.o. every 4-6 h), and dihydrocodeine (starting from $60 \mathrm{mg}$ p.o. every $12 \mathrm{~h}$ ). Very strong pain was managed using medications of the third step of the analgesic ladder, including buprenorphine (0.2/ $0.4 \mathrm{mg}$ as sublingual tablets of transdermal patches releasing the drug at the rates of $25 \mathrm{mg} / \mathrm{h}, 52.5 \mathrm{mg} / \mathrm{h}$ and $70 \mathrm{mg} / \mathrm{h}$ for $72 \mathrm{~h}$ ), fentanyl (transdermal patches releasing the drug at the rates of $25 \mathrm{mg} / \mathrm{h}, 50 \mathrm{mg} / \mathrm{h}$, and $100 \mathrm{mg} / \mathrm{h}$ for $72 \mathrm{~h}$ ) and morphine-containing products (Sevredol from $5 \mathrm{mg}$ p.o. every $4 \mathrm{~h}$, morphine hydrochloride $0.1 \%$ solution from 5 to $15 \mathrm{mg}$ p.o. every $4 \mathrm{~h}$, controlled-release morphine sulphate products from $30 \mathrm{mg}$ p.o. every $12 \mathrm{~h}$ ). The statistical analysis confirmed that strong or mild opioids were used in patients experiencing more severe pain than in patients receiving non-opioid drugs $(H=15.94$; $p<0.0003)$. Detailed data are presented in Table 1 .

No statistically significant relationship $(p>0.05)$ was observed between the intensity of pain and the time from mastectomy as well as the selected sociodemographic variables such as age, education, marital status, and place of residence. A statistically significant relationship was observed between the intensity of pain and the subjective evaluation of the subject's material status. Women who declared poor or adequate material status reported pain of a significantly higher intensity than women who declared their material status to be good or very good $(Z=-2.45$; $p<0.01)$.

Emotional state assessment results obtained in the patient population using the HADS-M questionnaire are presented in Table 2 . As shown by the analysis, about one-third of the patients were able to develop stress-coping strategies during their breast cancer treatment, allowing them to maintain anxiety and depression levels within the normal range (29.7 and 38.1\%, respectively). Normal aggression levels were maintained only by every one in 5 patients. Strong emotional stress manifested by anxiety and depression was experienced by $48.3 \%$ and $29.7 \%$ of patients, respectively. Aggression was experienced by $15.2 \%$ of patients.

No statistically significant relationship $(p<0.05)$ was observed between the intensity of anxiety, depression, and aggression and the analysed sociodemographic variables including age, education, professional activity, residence, marital status, parity, and material status.

A positive relationship between the intensity of pain and the analysed emotional states was observed. Intensification of pain was associated with intensification of anxiety ( $r=0.37 ; p<0.0001)$, depression $(r=0.35 ; p<0.01)$, and aggression $(r=0.30 ; p<0.01)$. Mean pain intensity values in the context of levels of emotional states analysed in the study are presented in Table 3.

\section{Discussion}

This study analysed the type of chronic pain due to breast cancer treatment, including radical

Table 1. Treatment of cancer pain in the study group

\begin{tabular}{|lccc|}
\hline Analgesic ladder step & Analgesic drug type & \multicolumn{2}{c|}{ VAS pain intensity } \\
\cline { 3 - 4 } I & Arithmetic mean & SD \\
II & Non-opioid & 2.48 & 1.66 \\
III & Mild opioid + non-opioid \pm adjuvant drugs & 3.71 & 1.75 \\
$H=15.94 ; p<0.0003$ & Strong opioid + non-opioid \pm adjuvant drugs & 3.64 & 1.47 \\
\hline
\end{tabular}

Table 2. Numbers and percentages of HADS-M scores in the study group

\begin{tabular}{|c|c|c|c|c|c|c|c|c|}
\hline \multirow[t]{3}{*}{ HADS-M Subscale } & \multicolumn{6}{|c|}{ Level } & \multirow{2}{*}{\multicolumn{2}{|c|}{ Total }} \\
\hline & \multicolumn{2}{|c|}{ Normal } & \multicolumn{2}{|c|}{ Borderline } & \multicolumn{2}{|c|}{ High } & & \\
\hline & $n$ & $\%$ & $n$ & $\%$ & $n$ & $\%$ & $n$ & $\%$ \\
\hline Anxiety & 35 & 35 & 26 & 22.0 & 57 & 48.3 & 118 & 100 \\
\hline Depression & 45 & 45 & 38 & 32.2 & 35 & 29.7 & 118 & 100 \\
\hline Aggression & 25 & 25 & 75 & 63.6 & 18 & 15.2 & 118 & 100 \\
\hline
\end{tabular}


Table 3. Mean pain intensity scores vs. intensity of negative emotions as assessed using the HADS-M scale in the study group

\begin{tabular}{cccccc}
\hline \multicolumn{2}{c}{ HADS-M } & & \multicolumn{2}{c}{ VAS } \\
\cline { 1 - 2 } Subscale & Level & & $\begin{array}{c}\text { Arithmetic } \\
\text { mean }\end{array}$ & SD \\
& Normal & & 2.23 & 1.33 \\
& Borderline & & 2.88 & 1.82 \\
& High & & 3.72 & 1.72 \\
\cline { 5 - 5 } Depression & Normal & & 2.62 & 1.61 \\
& Borderline & & 3.21 & 1.54 \\
& High & & 3.57 & 2.00 \\
& Normal & & 2.44 & 1.45 \\
& Bggression & Borderline & & 3.08 & 1.78 \\
& High & & 4.06 & 1.66 \\
\hline
\end{tabular}

surgery and chemotherapy. Patients were treated for pain in a mainly symptomatic manner. According to estimates made in the studies by Schou Bredal et al., chronic pain due to breast cancer treatment may affect $25-60 \%$ of patients, regardless of the clinical stage of the disease [3]. On the other hand, as pointed out by Brzeziński [8], the incidence of chemotherapyinduced peripheral neuropathy (CIPN) in the population of Polish oncological patients is estimated at $3-7 \%$ for the treatment using one cytostatic drug and up to $38 \%$ upon cytostatic polytherapy.

The study subjects assessed the pain intensity using a 10-point NRS scale; the results were in the range 1 to 8 , with a mean score of $3.09(\mathrm{SD}=1.75, \mathrm{Me}=3)$. As shown by the data in Table 1, the implementation of cancer pain pharmacotherapy principles in the study population allowed nearly $50 \%$ of the patients $(n=58$; $49.2 \%)$ to experience pain at a mild, acceptable level (arithmetic mean score of 2.48). The remaining patients receiving analgesic treatment according to the second and third step of the analgesic ladder assessed the pain intensity to be moderate (arithmetic mean 3.64 to 3.71 ). Pain intensity results within the study population are close to those obtained in a group of Norwegian patients undergoing breast cancer treatment. Data were obtained from $63 \%$ of the total of 832 female patients qualified for the study. A total of $41 \%$ patients within the study group reported pain, including mild pain reported by $51 \%$, moderate pain reported by $41 \%$, and strong pain reported by $8 \%$. A total of $33.8 \%$ of all pain-experiencing patients reported signs and symptoms of neuropathic pain [3] Danish studies presented by Gärtner et al. [9] showed that pain is also a serious clinical problem 2-3 years after, completion of breast cancer. Out of the total of
3754 women aged 18-70 years and having undergone breast cancer treatment, pain was experienced by $47 \%$ of patients; of those, strong, moderate and mild pain was experienced by $13 \%, 39 \%$, and $48 \%$, respectively. Similar results were presented by Belfer et al. [10]. One-third (32.5\%) of patients at 35.4-38.3 months after mastectomy procedure experienced pain of an intensity $\geq 3$ on a 10-point scale. Analyses presented by the research groups of Schou Bredal et al. [3] and Gärtner et al. [9] demonstrate that a significantly stronger pain was associated with resection of axillary lymph nodes, chemotherapy, radiation therapy, and younger age of patients. The studies conducted by Scheridan et al. [11] pointed out a five-fold increase in post-mastectomy pain risk in patients experiencing moderate to strong pain in the preoperational period. Chemotherapy increases this risk by a factor of three.

In the studies conducted by Kulpa and StypułaCiuba [2] and involving a group of Polish Pain Treatment Clinic patients with cancer history of at least 6 months, including female patients with breast cancer, the mean pain intensity in a $0-10$ VAS scale was 6.8. Such high intensity of pain was experienced by as many as $59 \%$ of patients. As few as $7(8.4 \%)$ of the patients experienced pain of low intensity, graded as $0-3$ points on the visual assessment scale. Within the sensory dimension, pain was most commonly described as sharp (54\%), throbbing (49\%), and radiating (39\%). In emotional categories, the most common descriptions included exhausting (43\%), disturbing (26\%), and horrible (23\%). High intensity of pain might, on the one hand, be associated with a specific natural history of the cancer and the course of the therapy. On the other hand, however, particularly in patients receiving care in an outpatient setting, it might be determined by the patients' inappropriate management of pain and other disease symptoms as well as to their lack of self-care capabilities or skills [12]. Pacian et al. [13] point out the importance of support in the management of cancer pain patients, suggesting it as an important predictive factor. In her study, the author demonstrated that a key role in the support system is played by family and friends (77.5\%), allowing for candid talks about the pain experienced by the patient. An important problem for patients experiencing pain is the ability to obtain financial support, provided by the family in $57-76 \%$ of patients, depending on age. In our own studies, poor and adequate material status was an important determinant of higher pain intensity being declared $(p<0.01)$.

Due to the scale of the phenomenon, persistent postmastectomy pain (PPMP) is increasingly considered to be one of the main problems of individual and social life [10]. The prevention and treatment of neuropathic pain in oncology remains a difficult clinical problem, instigating continuous search for novel strategies of oncological patient care [8, 14-16]. 
Persistent pain, being a disorder per se, has numerous physical and behavioural consequences, such as sleep disorders, appetite disorders, irritability, abandonment, lower libido and sexual activity, motor impairment, fatigue, reduced pain threshold, and concentration difficulties. Long-term experience of pain is also associated with an emotional component manifesting as negative emotional reactions such as anxiety, depression, as well as revolt and aggression [17].

The relationship between pain and anxiety is particularly significant. Anxiety is a response to threat and increases the pain being experienced, while the pain deepens the feeling of anxiety. Strong pain exacerbates other physical disorders and leads to emotional problems. Numerous studies [2, 3, 18-20] provide results that confirm the negative correlation between the intensity of pain and worse emotional, physical, and social functioning of patients. The results of our own studies presented herein confirm the statistically significant relationship between the intensity of pain and the increase in the levels of anxiety, depression, and aggression. Of note is the fact that when pain pharmacotherapy was used allowing the pain to be maintained at a generally low and moderate level (Table 1), a high level of anxiety was experienced by nearly half of the patients (48.3\%), while high levels of depression and aggression were experienced by $29.7 \%$ and $15.2 \%$, respectively. This might be explained by the effects of chemotherapy. As demonstrated by research, chemotherapy lasting for several months and causing typical early and delayed adverse effects induces a significantly higher level of negative emotional reactions in patients [21-23].

Authors of numerous studies of emotional adjustment to cancer highlight the importance of personality-related factors and the implemented disease-coping strategies. According to studies cited by de WaldenGałuszko et al. [24], the incidence of adaptational disorders is estimated within the range $16-42 \%$, with the incidence of "depressive syndromes" being 25\%. During remission periods lasting up to 1 year, the problem affects $15 \%$ of the patient population, increasing to $45 \%$ in the most traumatic periods of relapse. Reports on anxiety suggest the incidence in the range $10-30 \%$. The author points out that female patients are more prone to adaptational disorders compared to male patients.

Studies have shown that anxious-preoccupied, helpless-hopeless, and destructive strategies of coping with cancer are associated with worse emotional and cognitive as well as physical and social functioning. On the other hand, adopting an attitude of fight, positive rearrangement of values, and constructive strategies of coping with cancer allowed patients to achieve a better emotional dimension of the quality of life [2]. Despite experiencing severe stress associated with cancer treatment involving surgery, radiation therapy, and chemotherapy and thus promoting unfavourable emotional changes, patients are usually capable of accepting their disease and adopting constructive coping strategies with time from the completion of the treatment $[25,26]$.

The complexity of therapeutic methods used to treat breast cancer as well as adverse functional consequences of treatment in cancer patients requires constant monitoring of both early and delayed quality of life. The analysis of the intensity of chronic pain as one of the main problems in oncological care becomes of special importance. Effective treatment of chronic cancer pain may prevent numerous adverse psychosomatic and social consequences for patients. The analysis of data obtained in this area is also of key importance for the improvement in nursing practices as well as for the development of self-care abilities in patients.

\section{Conclusions}

Adherence to the WHO-recommended analgesic ladder regimen is an effective means to treat chronic cancer pain in women in the final stage of chemotherapy following radical surgical treatment. Effective pharmacotherapy of cancer pain significantly contributes to a reduction in the intensity of negative emotional reactions, i.e. anxiety, depression, and aggression in patients undergoing chemotherapy following mastectomy. Breast cancer chemotherapy is associated with high levels of anxiety, pain, and aggression experienced by the patients. Nursing care is associated with the need to monitor the emotional state of patients early after radical surgery and chemotherapy of breast cancer, with consideration being paid to a wide spectrum of circumstances, mainly the presented physical symptoms, including pain. At the analysed stage of cancer care, social support provided by nurses should be aimed particularly at helping patients to develop and employ constructive diseasecoping strategies.

\section{References}

1. Jarosz J, Hilgier M. Zasady diagnostyki i leczenia bólu. In: Podstawy opieki paliatywnej. de Walden-Gałuszko (ed.). PZWL, Warsaw 2007; 20-49.

2. Kulpa M, Stypuła-Ciuba B. Ból nowotworowy i uciążliwość objawów somatycznych a jakość życia u pacjentów z chorobami nowotworowymi. Med Paliat 2013; 5: 171-9.

3. Schou Bredal I, Smeby NA, Ottesen S, et al. Chronic pain in breast cancer survivors: comparison of psychosocial, surgical, and medical characteristics between survivors with and without pain. J Pain Symptom Manage 2014; 48: 852-62.

4. van den Beuken-van Everdingen MH, de Rijke JM, Kessels AG, et al. Prevalence of pain in patients with cancer: a systematic review of the past 40 years. Ann Oncol 2007; 18: $1437-49$. 
5. Dobrogowski J, Krajnik M, Jassem J, et al. Stanowisko dotyczące postępowania przeciwbólowego u chorych na nowotwory. Onkol Prakt Klin 2009; 2: 55-68.

6. Ciałkowska-Rysz A, Dzierżanowski T. Podstawowe zasady farmakoterapii bólu u chorych na nowotwory i inne przewlekłe, postępujące, zagrażające życiu choroby. Med Paliat 2014; 6: 1-6.

7. de Walden-Gałuszko K, Majkowicz M. Ocena jakości opieki paliatywnej w teorii i praktyce. Zakład Medycyny Paliatywnej, Akademia Medyczna w Gdańsku, Gdańsk 2000.

8. Brzeziński K. Obwodowa neuropatia wywołana chemioterapią. Część II. Zapobieganie. Współcz Onkol 2012; 16: 262-5.

9. Gärtner R, Jensen MB, Nielsen J, et al. Prevalence of and factors associated with persistent pain following breast cancer surgery. JAMA 2009; 302: 1985-92.

10. Belfer I, Schreiber KL, Shaffer JR, et al. Persistent postmastectomy pain in breast cancer survivors: analysis of clinical, demographic, and psychosocial factors. J Pain 2013; 14: $1185-5$.

11. Sheridan D, Foo I, O'Shea H, et al. Long-term follow-up of pain and emotional characteristics of women after surgery for breast cancer. J Pain Symptom Manage 2012; 44: 608-14.

12. Bischoff K, Weinberg V, Rabow MW. Palliative and oncologic co-management: symptom management for outpatients with cancer. Support Care Cancer 2013; 21: 3031-7.

13. Pacian A, Kulik TB, Skórzyńska H, et al. Rola wsparcia w bólu nowotworowym. Med Paliat 2014; 6: 95-10.

14. Brzeziński K, Chwedorowicz R. Opioidy w leczeniu polineuropatii wywołanej chemioterapią. Współcz Onkol 2011; 15: 251-5

15. Pickering G, Morel V, Joly D, et al. Prevention of post-mastectomy neuropathic pain with memantine: study protocol for a randomized controlled trial. Trials 2014; 15: 331.

16. Dzierżanowski T, Ciałkowska-Rysz A. Leki przeciwdrgawkowe w leczeniu adiuwantowym bólu nowotworowego. Med Paliat 2012; 4: 197-203.

17. Grabińska K, Szewczyk-Cisek I, Hernik P, et al. Problemy i potrzeby psychosocjalne pacjentów poddanych chemioterapii onkologicznej. Psychoonkologia 2011; 2: 39-47.

18. Helen JC, Lydersen S, Klepstad P. The Brief Pain Inventory: pain's interference with functions is different in cancer pain compared with noncancer chronic pain. Clin J Pain 2008; 24: 219-25.

19. Stepień R, Wrońska I. Lęk i depresja jako emocjonalne uwarunkowania możliwości funkcjonalnych kobiet po radykalnym leczeniu raka piersi. Stud Med 2008; 10: 31-5.

20. Kulpa M, Owczarek K, Stypuła-Ciuba B. Przystosowanie psychiczne do choroby nowotworowej a jakość życia uwarunkowana stanem zdrowia u chorych onkologicznie. Med Paliat 2013; 4: 106-13

21. Kim MY. Transition of symptoms and quality of life in cancer patients on chemotherapy. J Korean Acad Nurs 2009; 39: 433-45.

22. Groenvold M. Health-related quality of life in early breast cancer. Dan Med Bull 2010; 57: B4184.

23. Lim CC, Devi MK, Ang E. Anxiety in women with breast cancer undergoing treatment: a systematic review. Int J Evid Based Healthc 2011; 9: 215-35.

24. de Walden-Gałuszko K, Majkowicz M, Zdun-Ryżewska A. Zaburzenia przystosowania do choroby nowotworowej
- trudności diagnostyczne zespołów depresyjnych. Psychoonkologia 2013; 1: 10-5.

25. Milik A. Przystosowanie się do choroby u kobiet z nowotworem piersi przed mastektomią i po niej oraz przed zabiegiem oszczędzającym i po tym zabiegu. Psychoonkologia 2013; 2: 50-5.

26. Ogińska-Bulik N. Rola prężności psychicznej w przystosowaniu się kobiet do choroby nowotworowej. Psychoonkologia 2011; 1: 1-10.

\section{Address for correspondence:}

\section{Renata B. Stępień PhD}

Department of Oncology and Nursing Oncology

Institute of Nursing and Obstetrics

Faculty of the Sciences

Jan Kochanowski University

al. IX Wieków Kielc 19, 25-317 Kielce, Poland

Phone: +48 501208834

E-mail: renatas@ujk.edu.pl 